\title{
Participatory action research: Addressing social vul- nerability of rural women through income-generating activities
}

\section{Ms Liezel van Niekerk \\ Director: Jasiri \\ Tel: $+27(0) 182947162$ \\ liezel@jasiri.co.za \\ Dewald van Niekerk}

Director: African Centre for Disaster Studies, North-West University, Potchefstroom Campus, South Africa dewald.vanniekerk@nwu.ac.za

\section{ABSTRACT}

Participatory action research (PAR) is a robust and versatile research and development strategy. It can be utilised to: understand complex community structures and interaction; determine various types of vulnerability; assist in community capacity building and skills transfer; ensure community participation, and allow for the strengthening of livelihoods. This article focuses on PAR as a strategy, applying various methods and specific participatory tools to understand social vulnerability, within the context of women as rural farm dwellers in the North-West Province, South Africa. It emphasises the need for continued participation and highlights the practical principles and benefits derived from PAR. The PAR process cycles are discussed and parallels are drawn with the practical setting. In conclusion, the article emphasises that the application of the PAR process can make a multi-dimensional contribution towards the development of a community by creating an understanding of social vulnerability, by building capacity and by ensuring participation, and also addresses income-generating activities.

\section{KEYWORDS}

Participatory Action Research, income-generating activities, social vulnerability, rural women

\section{Introduction and background}

A considerable percentage of rural people (especially women) are trapped in poverty, with inadequate access to land, or some might even face landlessness (Mngxitama, 2004), with limited access to markets, no or limited employment opportunities, a lack of access to resources, the disintegration of social patterns, limited decision-making ability and a lack of information and knowledge (Rogerson, 2000; Siegel, 2005; Wisner in Bankoff, Frerks \& Hilhorst, 2004), to mention but a few. All of the above aspects significantly contribute to their social vulnerability (Wisner in Shaw \& Krishnamurthy, 2009; Dama \& Israt, 2004). Poor, rural farming commu- 
nities further face issues of poor infrastructure and limited services, including transport to the nearest cities. Rural farming communities as a result experience isolation, both from markets and employment opportunities and interaction with other communities (Mahmud, 2003; South African Human Rights Commission, 2003). These communities have limited access to assets, capabilities and consequently livelihood opportunities.

Productive and income-generating activities utilise local available resources and generally aim to benefit the entire community. These activities tend to reduce poverty and add to the feeling of well-being in rural communities (Mehra, 1997). Improved well-being (and the reduction of social vulnerability) is as a result achieved by the management of diverse assets including physical, human, financial, natural, intellectual and social assets (World Bank, 2002). Well-being (and in essence social vulnerability) is often more readily measured in terms of tangible aspects such as income and consumption, savings, food security, nutritional and health status (Siegel, 2005). Intangible measures of well-being, such as perceptions of self-esteem and empowerment, hope for the future; and leisure and recreation are mostly neglected when trying to understand social vulnerability (Wisner in Shaw \& Krishnamurthy, 2009). Although these intangible measures of rural development assist in understanding social vulnerability it is the tangible measures which directly reduce vulnerability. These include an understanding of household indicators such as age, income, gender, employment, other assets, disabilities, debt or savings and health insurance. Contributing indicators to community social vulnerability, on the other hand, focus on the intangible measures. Examples of an Australian government report on Quantifying Social Vulnerability include social participation, cooperation, community support, network size, emotional support, common action, bonding, bridging, linking or isolation (Dwyer et al., 2004:5)

Small and micro-enterprises are often the key players in rural development, due to the fact that they provide social structure and can address the difficulties which rural communities face (Fielden et al., 2003). Community members form groups, initially to provide a solution to unemployment or to supplement their current income. As a result of this action, micro-enterprises are formed with added benefits such as coherence, network forming, social integration, emotional support, but also social participation. Emmett (2000), as a result, emphasises the strong relationship between rural development and participation, with the assumption of the existence of a community and their ability to participate in their own development. The primary aims of rural development therefore include socialisation, with the focus on network building and developing of abilities. Secondary aims include institutional, political, economic, physical and social development (Botha, 1985; Du Preez, 1981a; Du Preez, 1981b; Hugo, 1981; Visser, 1985). Arnstein (1969) is of the opinion that there is no real citizen participation if there is no redistribution of power to the citizens or if they have not been included in future planning. In order to achieve the above aims it is imperative to understand the assets and resources in the community. Asset or resource assessments, utilising participatory strategies, place the emphasis on available resources and not on the lack thereof. Participative methodologies as a result suggest that communities are able to identify and satisfy their own needs, utilising local resources to the maximum (Kotzé, 1987; Wessels, 1990). Arnstein's ladder of citizen 
participation (1969) cautions that true power for citizens is achieved only through actual partnerships between all role-players and when power is delegated to citizens on a political level, in society and also on a financial level. Arnstein (1969) depicts citizen participation in a ladder format as various possibilities of participation, starting with manipulation and therapy, characterised as non-participation. Informing communities or citizens, consultation and placation are merely tokenism according to Arnstein, where partnership, delegated power and citizen control are viewed as the only true form of citizen power transfer.

Collins and Ison (2006) go one step further in describing the practice of participation, where the community needs, such as those of rural farm dwellers, are often neglected by the state. They further argue that a ladder for citizen participation, such as that of Arnstein (1969), could not be practical, because within communities a "complex set of relationships between roleplayers" exists (Collins \& Ison, 2006:5). Collins and Ison (2006:5-6) further argue that no ladders could possibly exist in a free space, such as rural communities that are faced with complex challenges. It is also possible that certain individuals might not have the need for power, but simply find interest in their basic needs being met. Social learning as a tool to address these basic needs can play an important role in collective engagement with others, questioning norms and policies with the objective of interactive processes involving multiple stakeholders. As a result a number of factors for community participation need to be taken into consideration, such as interdependencies, complexity, uncertainty and controversy (Collins \& Ison, 2006:6).

With the above background in mind, this article will focus on participatory action research (PAR) as a strategy, applying various methods and specific participatory tools to understand social vulnerability, within the context of women as rural farm dwellers. The practical setting where the PAR methods and commitments will be applied is in a rural farming community in the North-West Province, South Africa. The rural women from the farming community, experience a number of difficulties in their own unique setting. These difficulties include lack of income opportunities, low levels of education, isolation and limited transport opportunities to name but a few (Van Niekerk, 2006). These difficulties force the women to find alternative income sources. Income-generating activities provide these women with an opportunity to create jobs in the community through applying entrepreneurial skills and traditional skills and knowledge.

The community's income-generating project had, at the time of the study, been in existence for at least eight years. The initial aim of the participation partnership was purely the transfer of skills towards income-generation at the request of a small group of women in the community (Van Niekerk, 2006). It was recognised at the time that a PAR strategy could assist in the business and practical skills transfer to the women, in order to build and expand on existing knowledge, skills and resources. Business skills included budgeting, costing, marketing and general administration. Practical skills training included production planning, design, pattern making, sewing construction, and quality control. This was an attempt from the community's side to address their economic vulnerability status. With time, a need for participation and the delegation of power and decision-making naturally arose from the various stakeholders. 
This would ultimately address social vulnerability with specific reference to social patterns in the community. The stakeholders included the interested women from the community who established the project, markets, and individuals supportive of the products produced within the project, and the project facilitators.

Although there are various dimensions of vulnerability, including political, social, economic and environmental vulnerability (Dama \& Israt, 2004:8), the focus of this article will be limited to the dynamics associated with social vulnerability. Progress in levels of participation was observed against the specific indicators found for community social vulnerability from an Australian government report on Quantifying Social Vulnerability (Dwyer et al., 2004:5) and causes of vulnerability (Dama \& Israt, 2004:8). The indicators that were observed in this study were social participation, cooperation, community support, network size, emotional support, common action, bonding, bridging, linking and isolation. The causes among others, included poverty, poor health, low levels of education, gender inequality, lack of access to resources and services, which included knowledge and disintegration of social patterns. The study did not focus on quantifying these but merely on observing and reflecting on specific outcomes during the PAR process. The PAR process could therefore assist rural communities to focus on their available resources and build on current capabilities. Available literature was consulted to provide an overview of PAR as well as the need for, and practical benefits of, PAR in rural communities. The link was furthermore established with regard to the role of income-generating activities, social vulnerability reduction, poverty and PAR, with a strong emphasis on a peoplecentred approach. Income-generating activities and PAR were as a result applied as a vehicle to address the specific community indicators for social vulnerability.

An application of PAR, interlinked with the indicators of community social vulnerability, will be used to illustrate the benefit of PAR as both a strategy of addressing social vulnerability, and also facilitating participation in an income-generating project.

\section{Social vulnerability and its underlying causes}

Social vulnerability remains an ambiguous term (Wisner in Shaw and Krishnamurthy, 2009) covering a large domain of knowledge and understanding (Wisner in Bankoff, Frerks \& Hilhorst, 2004). Social vulnerability varies across time and space. This term reflects “...the degree to which societies or socio-economic groups are affected by stresses and hazards, whether brought about by external forces or intrinsic factors - internal and external - that negatively impact the social cohesion of a country" or community (UNDP, 2000). Cutter, Boruff and Shirley (2003) note that socially created vulnerabilities are mostly ignored in disaster assessments and in the creation of an understanding of disaster risk, due to the difficulty in quantifying them. They indicate: "instead, social vulnerability is most often described using the individual characteristics of people (age, race, health, income, type of dwelling unit, employment)" and gender.

A perusal of disaster risk management literature and vulnerability studies clearly indicates that in essence social vulnerability is driven by other components of vulnerability (such as 
environmental, physical, economic, and political vulnerability) (Cutter, 2001; Tierney et al, 2001; Putnam, 2000; Blaikie et al., 1994; Wisner et al, 2004; Wisner in Shaw \& Krishnamurthy, 2009). A number of indicators can be developed in order to measure social vulnerability but all of these will have time/space limitations. Such limitations make comparison across geographical areas quite problematic. As Wisner (in Shaw \& Krishnamurthy, 2009) indicates, the best method of understanding social vulnerability is through participatory interventions. In this case, the "facilitator seeks to understand the reality on the ground and finds the way forward together with the participants."

\section{Poverty and social vulnerability}

Poverty has many implications, definitions and aspects to it, but for the purpose of this article it is necessary to reinforce the strong link between poverty and social vulnerability. Poverty is often defined, together with various other indicators, in terms of access to resources and income opportunities (Dama \& Israt, 2004:1). Yodmani (2001) in Dama and Israt (2004:2) mentions that poor people identify vulnerability as a condition that takes account of their exposure to risk and their defencelessness in the face of their situation. Defencelessness in turn points to social marginalisation, which could result in economic marginalisation. Defencelessness is also "the lack of means to cope without damaging loss" (Chambers, 1989; Dama \& Israt, 2004:8). "Loss" is measured as being "physically weaker, economically impoverished, socially dependent, humiliated or physiologically harmed (Dama \& Israt, 2004:7). Poverty, vulnerability and asset ownership (or access to assets) are as a result linked (Chambers, 1989).

\section{The need for participation}

Unemployment and reduced income opportunities are indicators which are used in almost all cases by researchers to measure social vulnerability (Dama and Israt, 2004; Chambers, 1989; Ayson, 1993). Rural women experience difficulty finding employment opportunities for various reasons. These could include: family obligations, such as limited childcare opportunities, lack of appropriate skills and education, and limited job opportunities (Sandbeg, 2003; Fielden et al., 2003). A shortage of skills and illiteracy increase the lack of self-confidence, leading to a feeling of helplessness (Siegel, 2005; Horn, 1993). Poverty, lack of employment opportunities and limited income (all of these being causes of vulnerability), motivate women to engage in income-generating activities (Mavalela et al., 2002; Manning, 1993; Wentzel, 1993; Nobanda, 1998). A solution to the dilemma of unemployment would be to become self-employed and to increase the level of education and training. PAR can therefore be utilised as a strategy to address skills shortages and facilitate community participation, while simultaneously providing a valuable understanding of social vulnerability.

Participation acts as the mechanism to implement PAR and is essential at all stages of any project in order to ensure optimal benefit to those individuals most in need (Ngobese \& Cock, 1995). Participation encourages co-operation, negotiating skills, leaning to debate, finding purpose, but most of all, decision-making (Bremner $\&$ Visser, 1995). Creating a participative learning environment is essential to achieve a multi-dimensional economic, social and environ- 
mental measure of well-being (Moser, 1998; Carney et al, 1999; Coudouel \& Hentschel, 2000; Narayan et al, 2000). Community members or participants become active change-agents, engaging in collective, self-reflective inquiry. Self-belief is created in participants to bring about change within their own lives (Todhunter, 2001), thus addressing the core of social vulnerability. The community is furthermore directly involved in the design, generation, implementation, interpretation and dissemination of data and information with regard to project operations (Gardner, 2004).

Social vulnerability reduction, as a result, is achieved through a people-centred approach by encouraging self-help, self-reliance and empowerment (Möller et al., 2002; Mehra, 1997; Mavalela et al., 2002). Income-generating projects with a people- centred approach provide communities with the opportunity to generate an additional income, and gain self-respect and dignity (Mavalela et al., 2002). People's needs are addressed in this way and available resources are used in order to adopt a more participatory approach. A people-centred approach ensures that individuals become active participants, thus providing themselves with opportunities and not simply receiving benefits (Möller $e$ t al., 2002). Community participation takes place when the individuals of the community become actively involved in the development process. Participatory techniques acknowledge individuals to be knowledgeable of their own circumstances and immediate environment, and able to address their challenges (Khanlou \& Peter, 2005). Wisner (in Shaw \& Krishnamurthy, 2009) is of the opinion that such participatory techniques inherently emphasise the identification of resources and capacities, and not only shocks and stresses. PAR therefore provides an enabling mechanism for participation and partnership, which forms a pillar to the success of rural income-generating projects, to ultimately address the root causes of social vulnerability.

\section{A brief description of PAR}

Kurt Lewin (1948) first mentioned PAR as bridging theory and practice, incorporating planning, action and investigating the results of actions. PAR originates from two research approaches, namely action research and participatory research. Khanlou and Peter (2005) are of the opinion that PAR is not a method of research, but rather an orientation to research. PAR is therefore defined as a combination of "social investigation, educational work and action" (Holman, 1987). Others define PAR as combined creation, transformation and control of knowledge, leading to a spiral process of planning, acting, achieving objectives and re-planning (McTaggart, 1989; Boersema \& Maconachie, 1995; Collins, 1999). For this reason PAR should be viewed as a strategy towards addressing vulnerability and not just a method.

PAR further recognises that there are many ways in which knowledge can be obtained and a strong emphasis is placed on the experiences of community members. Consequently qualitative and quantitative research methods can be applied when making use of the PAR strategy. Gardner (2004) describes PAR as "removing the distance between the objective observer and subjective subject and includes the community being studied as an active participant in the research, with an end goal of empowering the community to create change". 


\section{Practical principles and benefits derived from PAR}

PAR applied in a community setting, as an attempt to address social vulnerability, provides some benefits. These benefits can only be achieved once the principles of PAR are followed. Israel et al. (1998), McTaggart (1989) and Swanepoel \& De Beer (1996:24-29) indicate the principles of community-based and participatory research literature as a process to follow for implementation. These principles will be briefly alluded to below while also linking them to the case study in question.

(a). PAR recognises the community as a unit or entity. Communities are defined in terms of geographical area, with a common identity and shared destiny. This may be true in the case where a community was brought together as a result of employment opportunities, for example. The community members might as a result not have any other common interest than simply to earn a living, and being forced to live in a certain geographical area.

The women living on the same farm from where the income-generating project originated, can thus be defined as a community for the purpose of the study. They live and function within a larger geographical area. A number of other farming communities can be included in this geographical area. As a result, a number of interested women from one of the farming communities joined forces to increase their income opportunities and better their social status in the community.

(b). The strengths and resources of the community are built upon. This is done to support and reinforce traditional knowledge, skills and social structures in the community (Mavelela et al., 2002:62-63). Local knowledge, practices, ideas and assumptions are utilised to ensure sustainable development is brought about. These structures assist the community in their daily lives and encourage them to work together. Cultural and social coherence is achieved as a result and the community is able to face their difficulties as a group.

In the practical setting, there were a number of resources that could be utilised towards the income-generating project. These included a building to which the women had access, members in the group with previous needlecraft experience, and sewing machines being at their disposal. Most of the women resided close to the physical infrastructure needed for this project, and therefore no additional transport was necessary. Women were furthermore able to bring their children to work, due to the informal structure of their business. These working women indicated that adequate, affordable childcare seemed to be a pressing issue, and the fact that their children could accompany them to work, was seen as a project resource.

(c). Facilitate partnerships with the community during all phases of research. Israel et al. (1998) describe the phases of valid and continuous participation in research as problem identification, data collection, interpretation of results and the application thereof in the community.

From the start of the project, as many relevant role-players as possible were urged to pledge their involvement in the project. Building networks are vital in these rural communities due to 
their myriad challenges. The women therefore established private transport possibilities from the very start to ensure this would not be a hindrance in future to obtaining raw materials and to delivering orders. The academic institution involved provided training and financial planning or resources, assistance with obtaining orders and general marketing. Other institutions were furthermore approached to assist with free business training. Potential clients for the needlecraft products were also involved as partners to assist with buying and selling of products.

(d). The community should identify the core research issues. This should be done even though it might be necessary to obtain and apply skills from outside the community. The knowledge obtained and actions taken will then provide mutual benefit for all role-players during the entire research process.

From the onset of the project, the facilitators and other role-players had a vague picture of what had to be done in the practical setting. The ideas and core research issues were actually decided and planned at the planning stage of the PAR process. This was done in the form of community meetings with the interested women. At this stage, the issues of research output in the form of articles and community service as part of the institution's curriculum were identified as core activities for the facilitating role-players. The community identified an income, skills acquisition and training as their most pressing issues. These identified needs of the community became the driving forces behind the research conducted.

(e). PAR as a systematic process which promotes co-learning and empowers communities, measures and addresses social vulnerability. A systematic learning process provides information for action, typically towards improving financial and employment status and optimising resources.

The PAR cycles were followed in the project, namely planning, acting and implementation, observing, reflecting and re-planning. This was undertaken to provide structure and a strategy for research. As the research progressed the flexibility of the PAR strategy became evident, where moving back to a previous cycle in the strategy was possible, if the need arose. The anticipated skills level of the women seemed to be an example of such. The women indicated their skills level to be much higher than did the facilitator, based on their previous needlecraft courses and experience. A practical skills test confirmed the initial assessment by the facilitator. This meant that the group had to return to the planning stage to make room for additional training time.

(f). Sharing of information, resources and decision-making power is vital to the PAR process. This should be respectfully done, in an understandable language that acknowledges all partner contributions. At the same time the researcher is able to learn from the community, through sharing of knowledge and local theories. The community members, on the other hand, are given some valuable insight as to the research process.

The role-players (from different walks of life) experienced difficulties at first in trusting one another, and in sharing information and knowledge. The facilitator had to reach out to the 
community, by trusting the women enough, based on this PAR principle, to share all relevant knowledge and information as far as possible. It took some time (approximately six months) working together with the women to gain their trust. Communities as adult learners have valuable information to share for the learning process, including experiences and traditional knowledge. The women were able to work in partnership with other role-players to share resources and information in such a way. The women had little confidence at first and had no interest in making decisions. After they had been able to deliver a number of successful orders and were given more responsibility, they took decision-making into their own hands. Aspects of decision-making included production schedules, raw material purchases, and profit sharing and overtime schedules to be able to deliver on time.

(g). Role-players share experiences and reflect critically on knowledge obtained (Mavelela et al., 2002:62-63). Communities are also able to reflect on practices during the PAR process, whereby situational understanding is created. Personal journals aid in the reflecting process, and assist in recording real-life experiences.

Each facilitator kept a journal in order to assist in capturing the richness of the data. The journals were further utilised to keep records of small achievements, which are easily overlooked. An example was the first time the women suggested to the facilitator how a seemingly impossible delivery date for products could be achieved. Other successes included the first time the women were able to obtain and deliver their own orders, handle the administration and finances on their own, open savings accounts, train new members and start to outsource work they were unable to do.

(h). Recordkeeping of practices, including "judgements, reactions and impressions" is essential for measuring outcomes at each stage of the process. Participants are, as a result, also required to keep records of accomplishments during the entire process.

The first example of recordkeeping of practices on the project was that of profit sharing methods. A number of methods were initially employed which all proved unsuccessful. Looking back at the records it was possible to learn from past experiences and adapt accordingly.

(i). The PAR research process promotes partnership building and the establishment of trust. Most importantly, unsustainable social practice is changed through positive change in rural communities.

The PAR strategy followed encouraged partnerships with other local farming communities. For example the group of women was able to share its workload with neighbouring communities in order to achieve delivery dates. In doing so, other women were also given the opportunity to generate income, without the responsibility of running a small business.

(j). PAR generally originates as something small, bringing about "minor changes". PAR often guides the facilitator to a better understanding of the community and their delicate relationship with resources. It therefore starts with small cycles, including planning, acting, observing, reflecting 
and re-planning. It also involves small groups within the larger community. It is also these small changes which in the long-term have a significant developmental impact on a community (Hamdi, 2004).

The income-generating project did indeed start with small aims and objectives, namely skills transfer aimed at income generating. Following a PAR strategy in the long run, through minor every day "changes", much more could be achieved as network building and partnerships developed.

On the basis of these principles, a number of PAR process cycles can be identified. Arden (2007) adapted a "Cogenerative Model" of PAR from Elden \& Levin (1991), which describes the PAR process followed in the local community. The focus is especially on the knowledge and social capital (networks, local leadership, shared norms and values, and traditional knowledge), which the community contributes, versus the contribution of the outsiders, namely the researchers. Trust is built between the community and researcher and the PAR process starts, which is described as the "mutual, reflexive learning through 'co-generative' dialogue, drawing on and building social capital".

\section{A PAR strategy: process cycles}

PAR is a process of continuous cycles, where each cycle reflects the above principles. The various processes in the PAR cycles need not be rigid, but rather move forwards and backwards within the cycle, with the intention of gaining additional knowledge from the community. Each of these processes will be briefly discussed, namely planning, acting, observing, reflecting and re-planning. For each of these processes a parallel from literature, an example from the practical setting and the link to the social vulnerability community indictors will be established. The community indicators are (1) social participation, (2) cooperation, (3) community support, (4) network size, (5) emotional support, (6) integration in community, (7) common action, (8) bonding, bridging, linking or isolation, and (9) reciprocity. The parallel from the practical setting will try to address social vulnerability in a rural farming community.

\section{Planning}

Planning reduces insecurity, increases the effectiveness of the project, defines objectives in an unambiguous manner and provides opportunities for monitoring and evaluation (Kerzner, 1979). Planning includes vital steps, namely a SWOT analysis (strength, weaknesses, opportunities and threats), task breakdown structure, defining the work schedule and also financial planning (Miles, 2004; Strydom, 2005). Planning has to be flexible to accommodate learning experiences and difficulties encountered. These difficulties include the level of skills and available resources of rural communities. Planning as a result includes setting time frames for various projects or tasks in a participative manner (Babbie \& Mouton, 2001). Community members are therefore consulted and assisted in a continuous facilitation effort during the planning process.Planning which takes into consideration social vulnerability community indicators, makes room for social participation, where many stakeholders and role-players are consulted. The co-operation of the community is therefore another indicator of social vulnerability in- 
volved during the planning stage of PAR. Planning makes room for emotional and community support for all role-players, with common action as goal.

In the case of the women's income-generating project, community meetings were organised among the income-generating project group members and other interested stakeholders. This vital first step aimed to establish buy-in and project interest among community members. This was also the stage where the facilitator became familiar with the women, and established trust (Wasserman \& Kriel, 1997). Various role-players attended the meetings, including a local Non-Government Organisation (NGO), the appointed facilitator and researcher from the North-West University and women from the community. These meetings gave impetus to valuable brainstorming sessions to determine the initial key areas of concern in the community.

\section{Acting and implementation}

Project implementation comprises putting planning into action, and controlling and monitoring these actions. Analysing available resources at this stage eliminates duplicating of resource transfer, and allocates resources where they are most needed (Van der Waldt, 2003). Kotzé and Swanepoel (1983) identify requirements for the implementation of plans. These include the development of detailed actions which need to be taken in accordance with the original plan. These actions must be goal-directed and co-ordinated. Participation, action and implementation always have to occur at grassroots level. Action plans have to be adjusted from time to time, to accommodate changing circumstances, difficulties which arise and resource specifications, which might change.

It often seems possible that the principles of PAR and indicators of social vulnerability can be neglected during the acting and implementation stage. Facilitators and role-players involved in income-generating projects lose sight of these principles and become focused on income generation and not so much on addressing these social aspects. Facilitators consequently should include all role-players during acting and implementation of planning, to ensure networks are created, co-operation achieved, integration in the community occurs and bonding and bridging are established.

Acting and implementation in the women's income-generating project were conducted during four stages. These were: data collection; categorising the data into themes; identifying a way forward; and negotiation and establishing ownership.

From the data collected during group meetings and practical business training, a number of themes were identified, namely:

- Need for constant business training with follow-up training, and monitoring and evaluation thereof;

- Practical skills training for various products, for new members and when new products are being introduced;

- Need for a facilitator from within the community to be trained; 
- Desire and need to generate a sustainable income from product sales;

- The need to address project sustainability during all phases of production; and

- Introduction and design of sustainability indicators to measure progress and level of sustainability for present and future generations.

\section{Observing}

The observation stage of the PAR process comprises regular monitoring and evaluation from the start of the project, during and at the end of the project. Toseland and Rivas (1998) point out that commonly used methods for assessing members through observation include self-assessment, worker observations, and reports. Self-assessment is the process whereby individuals assess their own behaviour, by simply recalling, examining and reflecting on their actions with the help of other members or individuals. Self-observation relies on memory to a great extent and therefore self-monitoring could be implemented as a triangulation method. Self-monitoring makes use of data collection by the individual at regular intervals, and in specific situations (Toseland \& Rivas, 1998). Reports by other individuals include individuals who are familiar with the behaviour and action of specific individuals. These are typically women working in the same income-generating group. Data collected in such a manner should be reliable and valid, and not based on rumours or assumptions (Toseland \& Rivas, 1998).

A production-orientated micro-business leaves little or no time for observations and reflection, being focused on the timely delivery of the products. Stress is often experienced within the group to generate a substantial income for all, due to financial stresses typically experienced within micro-businesses. It is therefore the role of the facilitators involved to observe. Common mistakes during the PAR process may be detected. These include implementing action plans too rigidly and excluding some of the members in the process; there is no reciprocity, the community still feels isolated and links are not established.

At the start, middle and end of each training session associated with the income-generating project, participant observations were conducted. This practice was used to guide the facilitator and participants to achieve goals and objectives and to encourage life-long learning, which would ensure sustainability. For this reason, the acting and implementation phase, as well as the observation phase often ran concurrently. Observations were conducted during monitoring and evaluation of participants and evaluating the action plan.

\section{Reflecting}

Reflection is an essential part of the adult learning process, concentrating on learning experiences being applied in everyday living (Douglas, 1995). During reflection, individuals try to make sense of experiences, and find links between events, actions and feelings. The learning experience comprises concrete understanding, observation and reflection, thus forming abstract concepts and testing new situations (Kolb, 1984). Reflection is necessary for continued learning. The connection between the levels of reflection and the level of commitment and interest should not be underestimated. Reflection should as a result include communication of results to participants, providing time and opportunity to review and reflect (Babbie \& Mou- 
ton, 2001). Problem solutions should subsequently be debated with participants, exchanging information and knowledge. Programme evaluation in itself is a method of research, measuring and weighing the value of something (De Vos, 1998). Programme evaluation includes needs assessments, programme monitoring, impact studies, cost-effectiveness studies and utilisation assessments (De Vos, 1998). During the evaluation cycle, achievement of goals and objectives, the level of skills development and extent of empowerment are evaluated (Strydom, 2005). This is done in conjunction with the results and data gathered from observations.

Reflection at different levels, namely individual, group and community level, does provide valuable insights into the manner in which PAR as a strategy is implemented. Reflection with a social vulnerability focus assists communities to acknowledge and ponder the factors that contribute to the difficulties they experience. In a traditional sense, the facilitator would typically identify these factors from an external perspective, with textbook solutions. Reflection consequently provides realistic, community-based solutions.

Participative, reflective experiences within the income-generating project helped the women to grow and re-plan. Reflection and informal discussions combined in an excellent exercise to improve the women's self-confidence. The reflection phase included sharing of experiences and knowledge, while reflecting on possible recommendations for future training. The participants mostly did this reflecting during group meetings, role-play exercises and informal sessions such as tea breaks. Opportunities were given to the participants to speak freely in a relaxed environment regarding their experiences, both during training and the manufacturing of products. Creative ideas for new products as well as areas where additional training would be required were raised.

\section{Re-planning}

Rural community structures and needs change with time and this has a direct impact on social vulnerability. Re-planning as a result allows for an opportunity for improvement (Raborn, 2003). During the implementation, observation and reflection stages opportunities for future improvement are identified and noted, and are, as a result, implemented during the re-planning stage. Re-planning allows for support of broader social goals and objectives, such as political empowerment, addressing gender issues, and building social structures. During the replanning phase the recommendations and results were taken into consideration in order to plan for a new intervention such as the introduction of new products. Recommendations included the need for start-up capital, business training, and exploration of existing markets, as well as the discovering of new markets.

Re-planning takes place during all the other stages of the PAR process, due to the value added when errors are detected or information transfer and learning take place. Learning and knowledge transfer is relevant for all role-players during the PAR process. It is therefore clear that re-planning occurs as soon as these aspects are detected.

After re-planning the cycle of PAR continues, implementing the re-planning components into a new plan of action. These cycles have to continue for future generations and when new members are added to the income-generating group or ever-changing social structure of the 
community. This is done to spread the knowledge gained from past experiences, on route to ensuring sustainable communities.

\section{Conclusion}

This article aimed to provide the reader with some insight into the PAR process and its utilisation as a research strategy and developmental tool within the context of a study of women as rural farm dwellers. Firstly a brief description of social vulnerability was provided in order to put the application of the PAR process into context. Secondly the need for participation was emphasised. A brief description of PAR was provided and some practical principles and benefits were alluded to. The PAR process cycles received attention and the elements of planning, acting and implementation, observing, reflecting, and re-planning were discussed with reference to the actions taken in an income-generating project in the North-West Province, South Africa.

Rural farm dweller communities are faced with a number of challenges and difficulties, as reflected in the evidence from this article. Income-generating activities in this setting did provide hope for these income-deprived communities. PAR has consequently been identified as the vital ingredient with regard to understanding social vulnerability, the development of people, and also for women engaging in income-generating activities. In the article the factors contributing to social vulnerability were discussed, namely social participation, reciprocity, cooperation, community support, network size, emotional support, integration into the community, common action and bonding, bridging and linking. Although the article did not set out to quantify social vulnerability, it became evident from the practical setting that PAR can be utilised to address social vulnerability in a community, by focusing on income generating activities. During the various processes of the PAR strategy which was applied in the community income-generating project, all these indicators were discussed. Isolated communities, with low levels of education and limited or no income opportunities often do not have network opportunities to address their challenges. A PAR strategy in this setting provided the community with a way out of their immediate circumstances. The application of the PAR process can make a multi-dimensional contribution towards the development of a community by creating an understanding of social vulnerability, building capacity, ensuring participation and also addressing income-generating activities. 


\section{References}

ARDEN, C. 2007. Reflections on the 'Wider Benefits' of Participatory Action Research: GraniteNet Phoenix Phase I. [Web:] http://rpc2007.usq.edu.au/files/Reflections\%20on\%20PAR\%20-\%20 GraniteNet\%20Phase\%20I.pdf [Date of access: 21 September 2009].

ARNSTEIN, S.R. 1969. A Ladder of Citizen Participation. JAIP. 35(4): 216-224.

AYSAN, Y. F. 1993. Keynote Paper: Vulnerability Assessment. In: P. Merriman and C. Browitt, eds., Natural Disasters: Protecting Vulnerable Communities, p. 1- 14.

BABBIE, E. 2001. The practice of social research. 9th Ed. Belmont: Wadsworth.

BABBIE, E. \& MOUTON, J. 2001. The Practice of Social Research. Oxford: Oxford University Press.

BANKOFF,G., FRERKS,G \& HILHORST, D. 2004. Mapping vulnerability: Disaster, development and people. London: Earthscan.

BLAIKIE, P., CANNON, T., DAVIS, I. \& WISNER, B. 1994. At Risk: Natural Hazards, People’s Vulnerability, and Disasters. London: Routledge.

BOERSEMA, N. \& MACONACHIE, M. 1995. Between practice and paradigm :an exploratory study in participatory evaluation. Pretoria: Human Sciences Research Council.

BOTHA, A.H. 1985. Die bydrae van streekwelsynsrade tot gemeenskapsontwikkeling. Pretoria: Universiteit van Pretoria. (Skripsie M.).

BREMNER, D. \& VISSER, P. 1995. Negotiation, conflict resolution and human needs. (In Managing Sustainable Development in South Africa. Oxford: Oxford University Press).

CARNEY, D., DRINKWATER, M., RUSINOW, T., NEEFJES, K., WANMALI, S. \& SINGH, N. 1999. Livelihoods approaches compared: A brief comparison of the livelihoods approaches of the UK Department for International Development (DFID), CARE, Oxfam and the United Nations Development Programme (UNDP). London: Department for International Development.

CHAMBERS, R. 1989. Vulnerability, Coping and Policy. IDS Bulletin.20(2):1-7.

COLLINS, K. \& ISON, R. 2006. Dare we jump off Arnstein's ladder? Social learning as a new policy paradigm. UK: Open University.

COLLINS, K. 1999. Participatory research: a primer. Johannesburg: Prentice Hall.

COUDOUEL, A. \& HENTSCHEL, J. 2000. Poverty Data and Measurement. Preliminary draft for A Sourcebook on Poverty Reduction Strategies. Washington, D.C.: World Bank.

CUTTER, S.L. 2001. American Hazardscapes: The Regionalization of Hazards and Disasters. Washington, D.C.: Joseph Henry Press.

CUTTER, S.L., BORUFF B.J. \& SHIRLEY, W.L. 2003. Social vulnerability to environmental hazards. Social Science Quarterly. 84(2):243-261.

DAMA, P \& ISRAT, R. 2004. Vulnerability and Poverty: What are the causes and how are they related? Term paper for Interdisciplinary Course, International Doctoral Studies Program. Bonn: ZEF.

DE VOS, A.S. (ed.) 1998. Research at grass roots: a primer for the caring professions. Goodwood: J.L. van Schaik.

DOUGLAS, T. 1995. Survival in groups: the basics of group membership. Buckingham. Open University Press.

DU PREEZ, P.H. 1981a. Gemeenskapontwikkeling as produksie-inset vir swart landbou in SuiderAfrika. Pretoria: Universiteit van Pretoria. (Verhandeling D.Sc.). 
DU PREEZ, P.H. 1981b. Inleiding tot die teorie van gemeenskapontwikkeling. Pretoria: BENSO.

DWYER, A., ZOPPOU, C., NIELSEN, O., DAY, S. \& ROBERTS, S. 2004. Quantifying Social Vulnerability: A methodology for identifying those at risk to natural hazards. Australian Government: Geosciences Australia.

ELDEN, M, \& LEVIN, M. 1991. 'Cogenerative learning: Bringing participation into action research' in W. Foote Whyte (ed). Participatory action research. London: Sage Publications.

EMMETT, T. 2000. Beyond community participation? Alternative routes to civil engagement and development in South Africa. Development Southern Africa, 17(4):501-518.

FIELDEN, L., DAVIDSON, M.F., DAWE, A.F. \& MAKIN, P.F. 2003. Factors inhibiting the economic growth of female owned small businesses in North West England. Journal of small business and enterprise development, 10(2):152-166 [In Emerald Insight: http://www.emeraldinsight.com/1462-6004. htm [Date of access: 25 April 2005].

GARDNER, S. 2004. Participatory Action Research Helps Now. The Hispanic Outlook in Higher Education, 14:25-26.

HAMDI, N. 2004. Small Change: About the art of practice and the limits of planning in cities. London: Earthscan.

HOLMAN, B. 1987. Research from the underside. The British journal of social work, 7(6):669-683.

HORN, P. 1993. Empowering women: The Pakhamani Textile Cooperative. Indicator South Africa, 11(1):85-87.

HUGO, E.A.K. 1981. Gemeenskapontwikkeling. (In Hugo, E.A.K., Schoeman, J.H. \& Engelbrecht, J.F.P. Eds. Gemeenskapswerk. Pretoria: Heer Printers Ltd. 204 p.)

ISRAEL, B, SCHULTZ, A, PARKER, E \& BECKER, A. 1998. Review of Community-Based Research: Assessing Partnership Approaches to Improve Public Health. Annual Review of Public Health.

KERZNER, H. 1979. Project management: a systems approach to planning, scheduling and controlling. New York: Van Nostrand Reinhold.

KHANLOU, N. \& PETER, E. 2005. Participatory action research: considerations for ethical review. Social Science \& Medicine, 60:2333-2340, 19 Dec. 2004 [Web:] http://elsevier.com/locate/socscimed. [Date of access: 5 May 2005].

KOLB, D.A. 1984. Experiential learning. Englewood Cliffs, NJ: Prentice Hall.

KOTZÉ, D.A. 1987. Contradictions and assumptions in community development. Community development journal, 22(1)31-35.

KOTZÉ, D.A. \& SWANEPOEL, H.J. 1983. Guidelines for practical community development. Pretoria: Promedia Publications.

LEWIN, K. 1948. Resolving social conflicts: selected papers on group dynamics. New York: Harper \& Row.

MAHMUD, S. 2003. Women and the transformation of domestic spaces for income generation in Dhaka bustees. Cities, 20(5): 321-329. [Web:] http://www.elsevier.com/locate/cities. [Date of access: 5 May 2005].

MANNING, C. 1993. A stitch in time. Indicator South Africa, 11(1): 79-84.

MAVALELA, H.R., SCHENCK, R. \& O’NEIL, M. 2002. The story of “Phela o Phedise” income generating project. The Social Work Practitioner-Researcher, 14(1):48-66. 
McTAGGART, R. 1989. 16 Tenets of participatory action research. [Web:] http://www.caledonia.org. uk/par.htm. [Date of access: 19 September 2005].

MEHRA, R. 1997. Women, Empowerment and Economic Development. Annals of the American Academy of Political and Social Science, 554:136-149, Nov.

MILES, L. 2004. Die toepassing van projekbestuursbeginsels in die proses van plaasarbeiderbemagtiging. Potchefstroom: Noordwes-Universiteit. (Skripsie M.).

MNGXITAMA, A. 2004. Farm dwellers: citizens without rights: the unfinished national question (A paper presented at the land reform and poverty alleviation in southern Africa conference, 4-5 June 2001, held by the Human Sciences Research Council (HSRC) in Pretoria, South Africa. [Web:] http://www. landaction.org/display.php?article $=194$ [Date of access: 17 October 2005].

MÖLLER, P.H., SENEKAL, A. \& KRUGER, D.J.F. 2002. A People-Centred Approach to Alleviate Poverty and Sustain Development in South Africa. The Social Work Practitioner-Researcher, 14(1):26-47.

MOSER, C. 1998. The Asset Vulnerability Framework: Reassessing Urban Poverty Reduction Strategies. World Development, 26(1): 1-19.

NARAYAN, D., PATEL, R., SCHAFFT, K., RADEMACHER, A. \& KOCH-SCHULTE, S. 2000. Voices of the Poor: Can Anyone Hear Us? Washington, D.C.: Oxford University Press for the World Bank.

NGOBESE, P. \& COCK, J. 1995. Development and Environment. (In Managing Sustainable Development in South Africa. Oxford: Oxford University Press. p.260-276.)

NOBANDA, J. 1998. Assessing problems affecting small manufacturing: the case of clothing and metal-working in Soweto. Johannesburg: University of the Witwatersrand. (Unpublished).

PUTNAM, R.D. 2000. Bowling Alone: Collapse and Revival of the American Community. New York: Simon \& Schuster.

RABORN, G. 2003. A call for re-planning as a discipline of community planning. [Web:] http://www. planetizen.com/node/90 [Date of access: 5 December 2005].

ROGERSON, C.M. 2000. Successful SME's in South Africa: the case of clothing producers in the Witwatersrand. Journal of southern Africa studies, 26:687-718.

SANDBEG, K.W. 2003. An exploratory study of women in micro enterprises: gender-related differences. Journal of small business and enterprise development, 10(4):408-417. [Web:] http://www.emeraldinsight.com/1462-6004.htm [Date of access: 26 April 2005].

SHAW, R. \& KRISHNAMURTHY, R.R. 2009. Disaster Management: Global challenges and local solutions. Hyderabad: Universities Press (India).

SIEGEL, P.B. 2005. Using an asset-based approach to identify drivers of sustainable rural growth and poverty reduction in Central America: a conceptual framework. [Web:] http://www.livelihoods.org/ static/psiegel_NN270.htm [Date of access: 26 April 2005].

SOUTH AFRICAN HUMAN RIGHTS COMMISSION. 2003. Inquiry into human rights violations in farming communities. p. 171-202. Pretoria: SA Human Rights Commission. [Web:] http:// www.gov.za/reports/2003/farming.pdf [Date of access: 7 March 2004].

STRYDOM, H. 2005. Participatory action research. (In De Vos, A.S., ed. Research at grass roots: for the social sciences and human service professions. 3rd ed. Pretoria: J.L. van Schaik.) 
SWANEPOEL, H. \& DE BEER, F. 1996. Communication for development - a guide for fieldworkers. Johannesburg: International Thomson Publishing (Southern Africa) (Pty) Ltd. 64 p.

TIERNEY, K. J., LINDELL, M.K. \& PERRY, R.W. 2001. Facing the Unexpected: Disaster Preparedness and Response in the United States. Washington, D.C.: Joseph Henry Press.

TODHUNTER, C. 2001. Social research update (Undertaking Action Research: Negotiating the Road Ahead). Guildford: University of Surrey, Department of Sociology.

TOSELAND, R.W. \& RIVAS, R.F. 1998. An introduction to group work practice. 3rd ed. Boston: Allyn and Bacon.

UNITED NATIONS DEVELOPMENT PROGRAM (UNDP). 2000. Human Development Report 2000. New York: Oxford University Press.

VAN DER WALDT, G. 2003. Applied project management. Potchefstroom: PU for CHE. (MPGA 815.)

VAN NIEKERK, L. 2006. Women's income-generating activities in a disadvantaged farming community: Towards sustainability. Potchefstroom: NWU. (Dissertation M.).

VISSER, L.L. 1985. Hervestiging as ' $n$ onderdeel van gemeenskapsontwikkelling soos toegepas deur die Noord-Transvaalse Ontwikkelingsraad. Pretoria: Universiteit van Pretoria. (Skripsie M.).

WASSERMANN, I. \& KRIEL, J.D. 1997. Facts and Fallacies: Perspectives on Community Development. Pretoria: Wassermann \& Kriel.

WENTZEL, W. 1993. Clothing micro-enterprises: from rags to riches? Indicator South Africa, 11(1): 73-78.

WESSELS, C.E. 1990. Die bydrae van gemeenskapswerk, gemeenskapsorganisasie, maatskaplike beplanning en gemeenskapsaksie tot gemeenskapsontwikkeling : ' $\mathrm{n}$ teoretiese beskouing. Pretoria: Universiteit van Pretoria. (Skripsie M.).

WISNER, B., BLAIKIE, P., CANNON, T. \& DAVIS, I. 2004. At Risk: Natural hazards, people's vulnerability and disasters. 2nd Edition. London: Routledge.

WORLD BANK. 2002. LaVentana Newsletter. Volume 1. Latin American and Caribbean Social Development Unit, Washington, D.C. [Web:] http://www.worldbank.org/afrolatin. [Date of access: 26 April 2005]. 